\title{
Development and Validation of a Scientific Literacy Test on Global Warming Theme
}

\author{
Aristo Hardinata \\ Department of Science Education \\ School of Postgraduate studies UPI \\ Bandung, Indonesia \\ Aristo.hardinata.s.pd@student.upi.edu
}

\author{
Anna Permanasari \\ Department of Science Education \\ School of Postgraduate studies UPI \\ Bandung, Indonesia \\ Anna_permanasari2003@yahoo.com
}

\begin{abstract}
A research and development study was conducted to develop an scientific literacy instrument test in the global warming theme for middle school students. Random sampling method was used to involve 112 fifteen-year students who attend the natural science course at three middle schools in Bandung. The test was 36 multiple-choice item format which followed the framework PISA 2015 in the global warming theme encompassing three essential concepts, photosynthesis, environmental pollution and the causes and effects of global warming. Characteristics of the test was analyzed by using content validity ratio and classical test analysis, including test reliability, item content validity, item difficulty index, item discrimination index, point biserial coefficient and Ferguson's delta. The developmental result was 30 scientific literacy items in the global warming theme which is able to measure the expected concepts and discriminate between high and low-achieving students.
\end{abstract}

Keywords—scientific literacy; global warming; instrument test;

\section{INTRODUCTION}

The 2013 Curriculum trains students to more observation, questioning and reasoning in an integrate learning theme. The aim is to provide students with the necessary abilities to develop their creativity and have a complete knowledge about the environment and life, as well as having a strong personal foundation in the social life environment. It is in line with a term the "scientific literacy" that set by PISA [1].

However, in reality, Indonesia students' literacy ability lags far behind other countries which participating the OECD Program for International Student Assessment (PISA). Indonesia's PISA result tend to be stagnant since year 2000 to 2012, only acquire an average score below the international average score set by PISA [1,2]. Various efforts have been made by the governments in various aspects of learning at schools, one of which was a learning assessment.

Assessment and testing are an integral part of classroom learning [3]. Some research has been conducted relate scientific literacy assessment. Soobard and Rannikmae [4], did a research about assesing scientific literacy students by using interdicipline scenario, A.A Istri Rai [5], did a research about development scientific literacy test for junior high school using bali culture contexts and also Adeleke and Joshua [6] did a reasearch about development and validation of sientific literacy achieevment test to assess senior secondary school student's literacy acquisition in physics. In order to development scientific literacy skills of junior high school students, the test that needed is the test that correspond to the curriculum used, so in accordance with learning's purpose.

Anderson [7] says that the discrepancy between the assessment purpose and the learning can cause problems. If the assessment does not correspond to the learning objectives, assessment results can not reflect the achievement of learning objectives. Therefore, to improve student's scientific literacy in integrated science learning, besides the need to develop appropriate learning, also needed a good assessment to assess the learning.

That which leads the author to develop a scientific literacy test for middle school students learning using contextual theme for integrated science teaching. A scientific literacy test was developed under the theme of global warming. Global warming theme raised as a contextual theme with the students' everyday life and includes the integration of science concepts. The global warming theme also includes scientific literacy domain that is the context of science, science process competencies, content or knowledge of science and students' attitudes toward science.

\section{RESEARCH METHOD}

This study was a research and development method that is limited to a trial usage stage, as proposed by Sugiyono [8]. It consists of several stages of exploring the potential problems, gathering information, designing a product, validating the design, improving the design, and testing product designs. A scientific literacy test was developed in accordance with test blueprint that were prepared in the designing product stage. Each test item was constructed following the appropriate context of the global warming theme, and based on the aspects of PISA 2015 scientific literacy [1].

The constructed items represent each domain of scientific literacy, i.e. the competence, knowledge and attitudes This construction aims to the test items directly identify where the students' weakness lies. Distribution of item test in each domain of scientific literacy are presented in Table I. 
TABLE I. Distribution OF THE ITEM TEST IN EACH SCIENTIFIC LITERACY DOMAIN

\begin{tabular}{|l|c|c|}
\hline \multicolumn{1}{|c|}{ Literacy domain } & Item number & $\boldsymbol{n}$ \\
\hline Explaining phenomena scientifically & $3,5,21,22$, and 32 & 5 \\
\hline Interpreting data & $\begin{array}{c}4,11,12,13,15,19,25, \\
29, \text { and } 33\end{array}$ & 9 \\
\hline $\begin{array}{l}\text { Evaluating and designing scientific } \\
\text { enquiry }\end{array}$ & $1,7,16$, an 35 & 4 \\
\hline Content knowledge & $\begin{array}{c}2,9,17,23,24,28, \\
30, \text { and } 36\end{array}$ & 8 \\
\hline Procedural knowledge & 6,20, and 34 & 3 \\
\hline Epistemic knowledge & $8,14,26,27$, and 31 & 5 \\
\hline \multicolumn{1}{|c|}{ Attitude } & 10 and 18 & 2 \\
\hline
\end{tabular}

Scientific literacy test item on the global warming theme was developed in the simple multiple-choice format consists of four possible answers. Sample question can be seen in Fig. 1. An item test that has been developed further validated constructs or contents to see the item legibility and suitability with the scientific literacy domain.

\section{Depletion of Ozone $\left(\mathrm{O}_{3}\right)$}

The atmosphere is an ocean of air and a precious natural resource for sustaining life on earth. However, human activities both national and individual interests to cause harm to this common resource, especially damaging to the ozone layer that serves as a protective shield for life on earth. An ozone molecule consists of three oxygen atoms. The ozone molecule is very rare, less than 10 in a million molecules in the air. Every day the ozone is formed and decomposed or disappeared. However, for nearly a billion years, the presence of ozone in the atmosphere plays an important role in maintaining life on earth. Ozone protects life on earth. About $90 \%$ of ozone is found in the lining of statosfer instrumental absorbs ultraviolet radiation (UV-B) are dangerous from the sun. In the last decade the ozone depletion occurs because Chlorofluorocarbons (CFCs).

\section{(a)}

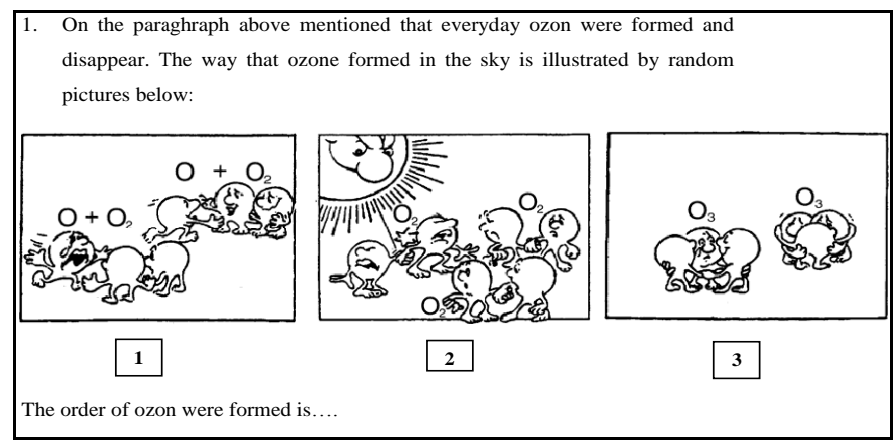

(b)
a. 1,2 , and 3
b. 1,3 , and 2
c. 2,1 , and 3
d. 2,3 , and 1

(c)

Fig. 1. A sample of scientific literacy item test on the global warming theme (a) context, (b) question, dan (c) options.

\section{RESULT AND DISCUSSION}

This section will explain the developmental result of the scientific literacy test on the global warming theme. The quality of the test refers to an overall test quality which includes validity and reliability test [9], as well as item test quality which includes the difficulty index $(\mathrm{P})$, discrimination index (D), and the point biserial coefficient (rpbi) [10].

\section{A. Construct validation}

A qualified test is a test that has good validity. It can be used to measure what we expect can be measured by the instrument test [9]. The construct validity were conducted by two faculty members and five experienced middle school science teacher uses a validation sheet suggested by Wilson et al. [11]. It is then analyzed using the Content Validity Ratio (CVR) [12] which the result is presented in Fig. 2.

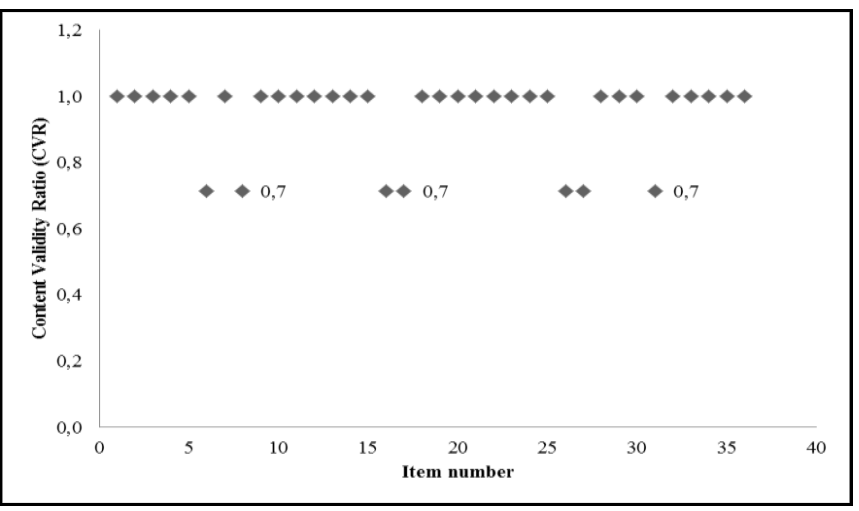

Fig. 2. Distribution of CVR score each test item.

Based on the CVR score of each test item, it is then compared with a CVRcritical score (0.62) of seven panelists (ne) [11]. The accepted test item if the CVR score larger than a score CVR critical.

\section{B. Reliability}

Scientific literacy test reliability was measured using the Kuder-Richardson formula (KR-20). KR-20 value of the scientific literacy test obtained at 0.75 . If the KR-20 is greater than 0.7 then a test is considered reliable for the group measurement, and if the KR-20 is greater than 0.8 it is a reliable test for use in assessing individual [10].

\section{Point biserial coefficient}

A point biserial coefficient is a measure of the reliability of each item test obtained from the correlation of scores per item with a total score [10]. Distribution of biserial coefficient per item can be seen in Fig. 3.

An acceptable point biserial coefficient is greater than or equal to 0.2 (rpbi $\geq 0.2)$ [10]. There are items which shows very low reliability compared to other items. These scores taken into consideration whether the item about maintained, revised or discarded, after previously analyzed related to difficulty and discrimination index. 


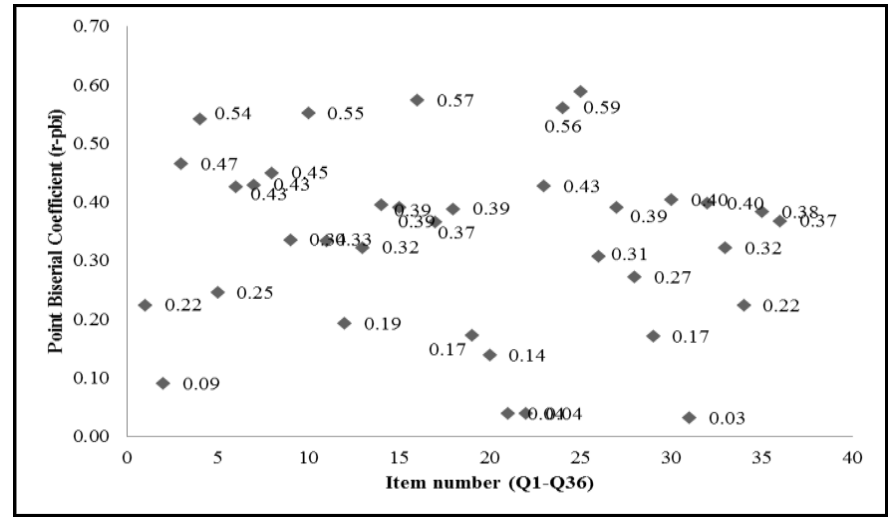

Fig. 3. Point biserial coefficient of each test item

\section{Difficulty index}

Difficulty index is a measure of the ease or difficulty of a test item. A good item test when its difficulty index is not too difficult and not too easy. The scientific literacy test had an average difficulty index of 0.70 . Judging from the average of difficulty index, the whole scientific literacy test item on the global warming theme has a moderate difficulty index. Specifications 36 item difficulty index of the science literacy test on the global warming theme can be seen in Fig. 4.

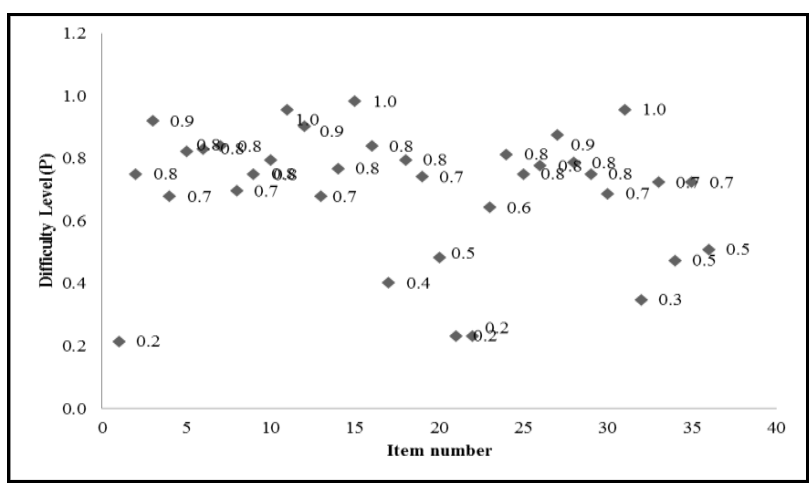

Fig. 4. Difficulty index of scientific literacy test item

An acceptable difficulty index range in the 0.3 to 0.9 [10]. There are several questions that showed a very low and very high, indicating that the items are very easy and very low, respectively.

\section{E. Discrimination index}

Discrimination index is a measure of the item's discriminatory power. By measuring the discrimination index, we can differentiate between high and low-performing students from the test results. The better the discrimination index, the better an item in distinguishing between high and low-ability students in the group. An acceptable value is equal to or greater than 0.3. The developed literacy test has an average discriminatory index of 0.32 . A complete data about each item discrimination index can be seen in Fig. 5 .

In Fig 5, it can be seen there are some items indicate the discrimination index was very low, even zero. These items will be considered for disposal.

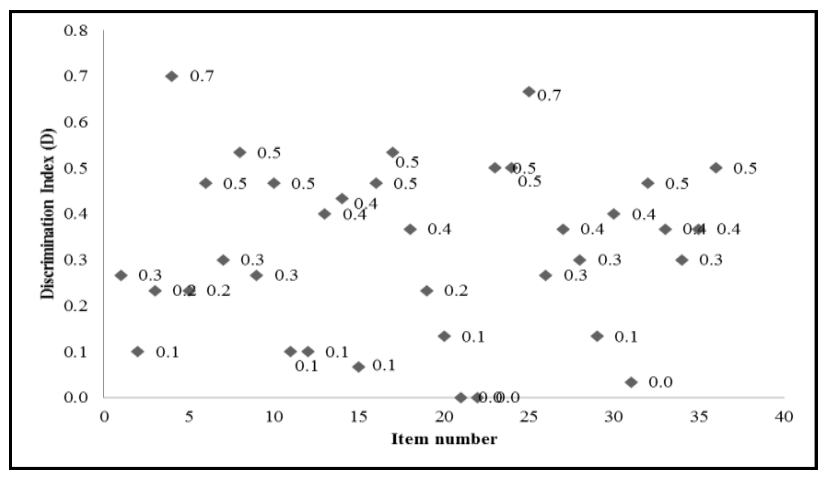

Fig. 5. Discrimination index of the literacy test items

\section{F. Ferguson's delta}

Ferguson's delta is a discriminatory power of the test as a whole. Ferguson's delta of the literacy test was 0.96. If a test has Ferguson's delta is greater than 0.90, then the test is considered to have great discriminatory power [10]. Recapitulation of the whole classical theory test analysis is presented in Table II.

TABLE II. RECAPITULATION OF CLASSICAL TEST AND CONTENT VALIDITY RATIO ANALYSIS

\begin{tabular}{|l|l|l|}
\hline Evaluation Measure & Values of the RCET & $\begin{array}{l}\text { Desired } \\
\text { Values }\end{array}$ \\
\hline Difficulty index $(P)$ & Average of 0.70 & $0.30-0.90$ \\
\hline Discrimination index $(D)$ & Average of 0.32 & $\geq 0.30$ \\
\hline Point biserial coefficient $(r-p b i)$ & Average of 0.33 & $\geq 0.20$ \\
\hline Reliability index $(r-K R 20)$ & 0.75 & $\geq 0.70$ \\
\hline Ferguson's delta $(\delta)$ & 0.96 & $\geq 0.90$ \\
\hline
\end{tabular}

Based on the classical and CVR test analysis, from the 36 questions were constructed, acquired 30 final items which have been revised and can be used as an assessment of scientific literacy test on the global warming theme. Six questions were discarded based on the consideration of an easy difficulty index category, low discrimination index, and low point biserial coefficient as an instrument test. It is clear that the sixth question is not able to measure what should be measured.

\section{CONCLUSION}

The development of scientific literacy test on the global warming theme for middle school students obtained 30 items which are valid and reliable. This test can discriminate well between high-performing students and low-performing students. Overall evaluation of the science literacy test on the global warming theme showed positive results. Thus, it can be used to measure the level of students' scientific literacy in learning about global warming theme, which encompasses photosynthesis, environmental pollution and the causes and effects of global warming. And can be used by teachers as an evaluation tool for teachers on materials related to the theme.

\section{References}

[1] OECD. PISA 2015: Draft science framework. Paris: OECD. 2013. 
[2] OECD. PISA 2012 Results: What student know and can do. Student performance in mathematics, reading, and science volume 1. Paris: OECD. 2010.

[3] Jacobs, L. C. dan Chase, C. I. Development and Using Test Effectively. San Fransisco: Jossey-Bass Publishers. 1992.

[4] Soobard, R., \& Rannikmäe, M. Assessing student's level of scientific literacy using interdisciplinary scenarios. Science Education International,133-144. 2011.

[5] Sudiatmika, A.A Istri Rai. Pengembangan alat ukur tes literasi sains siswa SMP dalam konteks budaya Bali. S3 disertasi, Universitas Pendidikan Indonesia. 2010.

[6] Adeleke, A. A., \& Joshua, E. O. Development and Validation of scientific literacy achievement test to assess senior secondary school student's literacy acquisition in physics. Journal of Education and Practice. Vol. 6, No. 7, 2015
[7] Anderson, L.W. \& Krathwol, D.R. Pembelajaran, pengajaran, dan asesmen. Yogyakarta: Pustaka Pelajar. 2010.

[8] Sugiyono Metode penelitian pendidikan: pendekatan kuantitatif, kualitatif, dan R\&D. Bandung: Alfabeta. 2013

[9] Aubrecht \& Aubrecht. Constructing objective test. American Journal of Physics. 51, 613. 1983.

[10] Ding Lin \& Beichner R. Approaches to data analysis of multiple-choice questions. Physical review special topics. Physics education research. 5, 20103. 2009.

[11] Wilson, R. F., Pan, W., Schumsky, A.D. Recalculation of The Critical Values for Lawshe's Content Validity Ratio. Association for Assessment in Counseling and Education. 2012.

[12] Lawshe, C. H. A Quantitative Approach To Content Validity. Content Validity II. A Conference Held at Bowling Green State University, 28, hal 563-575. 1975 